\title{
Interventions in entrepreneurial learning: Blended learning and ICT capacity
}

\section{Stephen Burgess}

Centre for Applied Informatics

Victoria University

Stephen.Burgess@vu.edu.au

\section{Scott Bingley}

College of Business

Victoria University

\section{Rafael Paguio}

College of Business

Victoria University

\section{Carolyn Woodley}

School of Policing Studies

Charles Sturt University

\section{Abstract}

The effective use of information and communications technologies (ICT) can benefit most small businesses. This article examines the design, development and delivery of a pilot blended learning program for entrepreneurial learning that targets the use of ICT by tradespeople. The study involves a case study of tradespeople in Australia who participated in a program designed to build their capacity to identify, use and evaluate ICT to enhance their business practices. The program combined traditional instructional approaches (through faceto-face and online sessions for delivering basic ICT concepts to participants) with learnercentred approaches (through a combination of student mentor visits and practical exercises to identify applications that were context-specific for each participant's business). A blended learning assessment framework is employed throughout the article to inform and evaluate various aspects of the program. Project participants rated the face-to-face sessions, student mentor visits and practical exercises as very effective. However, some participants could not free up the time from their employment to participate in all of the face-to-face classes. From a theoretical perspective, an amended blended learning assessment framework for the delivery of ICT programs to entrepreneurs is presented and potential lessons for the delivery of ICT concepts to entrepreneurs in the trades and similar vocations are proposed.

Keywords: Blended learning; entrepreneurial learning; ICT use; instructional approach; leaner-centred approach.

\section{Introduction}

The simple definition of 'entrepreneur' is that relates to an individual who commences or owns a business (either self-employed or as owner-manager) with the aim of expansion (van Praag and Versloot, 2007). However, an extended viewpoint contends that entrepreneurs tend to take more risks and be more innovative than regular small business owner-managers (Fernandes, 2016). Entrepreneurial learning refers to the learning process of entrepreneurs and the impact that this has on their own personal development and that of their businesses (Cope 
and Watts, 2000). A search of the literature on entrepreneurial learning reveals two major themes: learning by the entrepreneur and learning by the organisation (Erdélyi, 2010). This article addresses learning by entrepreneurs, particularly from the viewpoint of proactive behaviour by tradespeople to participate in a blended learning program developed to build their capacity to identify, use and evaluate ICT to enhance their business practices. It is important to note that this article discusses the use of ICT for two distinct purposes:

1. The use of ICT by entrepreneurs to improve their businesses (which is the focus of the blended learning training program)

2. The use of ICT by instructors to deliver the blended learning program.

Using a blended learning assessment framework (Wong, Tatnall and Burgess, 2014) as a lens of analysis, the study examines the preparedness of instructors and tradespeople for the blended learning program, the choice of blended learning options provided for the tradespeople and the impact of the program. An updated version of the blended learning framework that is specifically tailored towards the training of entrepreneurs in the trades and similar vocations is then proposed.

The article begins by discussing entrepreneurial learning in the context of tradespeople and moves on to discuss how blended learning could support the use of ICT by tradespeople. The blended learning assessment framework is introduced as a means of outlining the different stages involved in implementing a blended learning program. A case study involving a blended learning program that was developed and delivered to enhance the ICT capacity of tradespeople as enterprising business managers is then presented.

\section{Literature Review}

This literature review comprises two main sections. The first relates to the notion of entrepreneurial learning, tradespeople as entrepreneurs and how they use ICT. The second section relates to the use of ICT (through blended learning) for delivering training to tradespeople.

\subsection{Entrepreneurial learning - the use of ICT by tradespeople}

The theoretical approaches to describing entrepreneurial learning are divided into two major 'camps' - those that focus on the entrepreneur (and associated personal learning experiences and cognitive capabilities) and those that focus on the organisation (how learning occurs collectively within the business and via its external networks) (Erdélyi, 2010). These approaches are not mutually exclusive. Literature focussing on the entrepreneur is most prominent and broadly fits two categories (Erdélyi, 2010):

- $\quad$ Entrepreneurial learning as a type of management learning which results in an entrepreneur who specialises in setting up new ventures;

- $\quad$ Entrepreneurial learning that occurs at different stages of the entrepreneur's career. Here, entrepreneurship is a behaviour that is learned through experience. Erdélyi (2010) suggests that this area of the literature is the most developed of the two.

Entrepreneurial learning can occur in several ways. One approach is through training (such as executive and/or management training) that can take place in various locations such as universities, government agencies, large businesses, the small business workplace (Erdélyi, 2010) and, more recently, online. Another type of learning occurs through unplanned crises or 
chance occurrences in the business (Pittaway and Thorpe, 2012) through which entrepreneurs adapt their behaviour to survive and learn from the experience. In this case, the learning process occurs through finding answers to problems that are encountered (Fayolle and Gailly, 2008). This article is concerned with planned learning by entrepreneurs who are running small businesses. For the purposes of this article a small business is considered to have between one (sole trader) to 20 regular employees (Burgess et al., 2009)

\subsubsection{How entrepreneurial businesses can use ICT}

ICT is "the use of computers and other electronic equipment and systems to collect, store, use, and send data electronically" (Cambridge University Press, 2013a, para. 1). Effective ICT use can benefit most small businesses in many ways, such as adding value to good and services, reducing the level of involvement of intermediaries, reducing the cost of searching for information, reducing the cost of conducting transactions and promoting external networks (Martin and Wright, 2005). However, small businesses that use ICT need to have the skills to do so effectively. In these businesses, the responsibility of learning how to use ICT effectively typically falls upon owner-managers as it is less likely that they will be able to recruit staff with ICT skills into the business.

\subsubsection{Tradespeople and ICT use}

Niblock (2013, p.2) refers to a tradesperson as "a skilled manual worker whose status, economically and socially, is considered somewhere between a labourer and a professional. Examples of tradespeople might be welders or electricians. The practitioners possess a high degree of both practical and theoretical knowledge of their trade". Training for such entrepreneurs has traditionally been the domain of vocational education, where the focus is on preparation for specific work in non-professional jobs and developing the skills needed to carry out specific tasks (Kirkup, 2010). Knowledge in the trades area might be predominantly described as procedural knowledge (Biggs and Tang, 2011) or knowing how to do things. In Australia, the National Training System for Vocational Educational Training is responsible for delivering 'workplace specific' skills.

The use of ICT in small businesses is also influenced by the 'digital divide'. This refers to the gap which separates those who have access to ICT from those who do not. Srinuan and Bohlin's (2011) literature review of digital divide research found that early researchers examined physical access to technology as the main cause of the digital divide. More recently, factors such as socio-economic status and ICT knowledge and skills were also found to play a role in the adoption and effective use of ICT. Thus, the divide occurs where there are businesses who have both access (to the technology) and the skills to use it effectively and those who do not. It is important for entrepreneurs to possess both physical access to ICT and the knowhow to use it effectively.

Many trades businesses (certainly those examined as part of this study) are either sole traders or have very few employees. As an example, in Australia the construction sector (incorporating builders, electricians, plumbers and so forth) has the third highest proportion of small businesses of 20 industry sectors listed by the Australian Bureau of Statistics (2012). Sole trader businesses especially are often more interested in survival than growth and tend to lack a longer term strategic focus (Jones et al., 2014). Their primary motivation for existence is usually to retain autonomy and independence in operation. It may even be difficult to consider owner/managers of such businesses as entrepreneurs. However, there are some owner/managers who may be considered as being energetic and innovative (Gray and 
Gonsalves, 2002). If they are motivated to learn, interested in different topics, ask excellent questions and so forth then such owner/managers exhibit the characteristics of entrepreneurs (Löbler, 2006). The tradespeople participating in the study described in this article are referred to in this article as entrepreneurs as they exhibited an innovative attitude towards improving themselves and their business through the learning and adoption of ICT tools and importantly, had taken the initiative to participate in the course.

As mentioned earlier, this article examines a specific, planned instance of entrepreneurial learning. As such, it does not focus on learning that occurs through unplanned crises or chance occurrences (or critical incidents as described by Cope and Watts, 2000) - but rather through planned activities, such as training.

When considering educating entrepreneurs about ICT use, Walker (2001) examines how one training program to improve ICT skills was designed to 'cascade' from delivering generic (basic) ICT skills (required by most participants) to specialised training that is context-specific to certain trades. In Walker's example, early skills provided are predominantly technical (for instance, basic Internet use) to later ICT use that is more contextual (how the skills could be applied in the varied conditions of different trades businesses). This scaffolding suggests an initial need to understand basic ICT concepts that could then be extended to the use of ICT to support work activities.

\subsection{Blended learning - ICT as a tool for delivering training}

This section of the literature moves from how ICT can be used by entrepreneurs in their business to how it can be used to deliver training for entrepreneurs.

As part of a planned approach to entrepreneurship education, Fayolle and Gailly (2008) proposed a teaching model framework. At the ontological level, the framework examined such concepts as what education means in the context of entrepreneurship and outlines the roles of educators and participants. This article is concerned with the educational level, where considerations relate to identifying the target audience for the education (for whom?), the educational objectives (why?), program content (what?), the methods and pedagogies adopted (how?) and the evaluations of effectiveness (for which results?).

Perren (2003, p.517) suggested that "there is a growing consensus that entrepreneurs require flexible, learner-centred and informal mechanisms of support". Harrison and Leitch (2005) discussed the important role that ICT can play in such learning. Even participating in training programs that use ICT to assist in their delivery can raise the ICT skill level of participants (Elliott and Clayton, 2007) and provide access to training for those whose work conditions and/or location make it difficult to attend face-to-face training (Walker, 2001).

Using Fayolle and Gailly's teaching model framework, the areas of interest of this article at the educational level are:

- $\quad$ For whom:

- Why:

- What:

- How:

- $\quad$ For which results:
Tradespeople

To assist them to use ICT effectively within their businesses

Concepts related to effective ICT use within the business

Blended learning training program (see following discussion)

Effective use of ICT in the businesses. 
One term employed to represent combinations of ICT-based and face-to-face learning is blended learning. Bliuc, Goodyear and Ellis (2007) described blended learning as a mix of different methods, including face-to-face and online teaching, the latter often referred to as 'elearning' (Wong et al., 2014). The use of ICT to assist learning has been a focus within the information systems discipline. For instance, Overby, Slaughter and Konsynski (2010) examined the role that virtual environments can play in numerous disciplines, including education, and discuss the important of developing theories and frameworks to assess their implications for society. Gasson and Waters (2013, p.95) examined the engagement of learners in online courses and found "a dearth of useful theory about the strategies employed by learners to manage their engagement with the course and about the effect that learner strategies have on course outcomes".

Wong et al. (2014) introduced a 'Blended Learning Assessment' (BLA) framework to consider all aspects of blended learning (refer Figure 1).

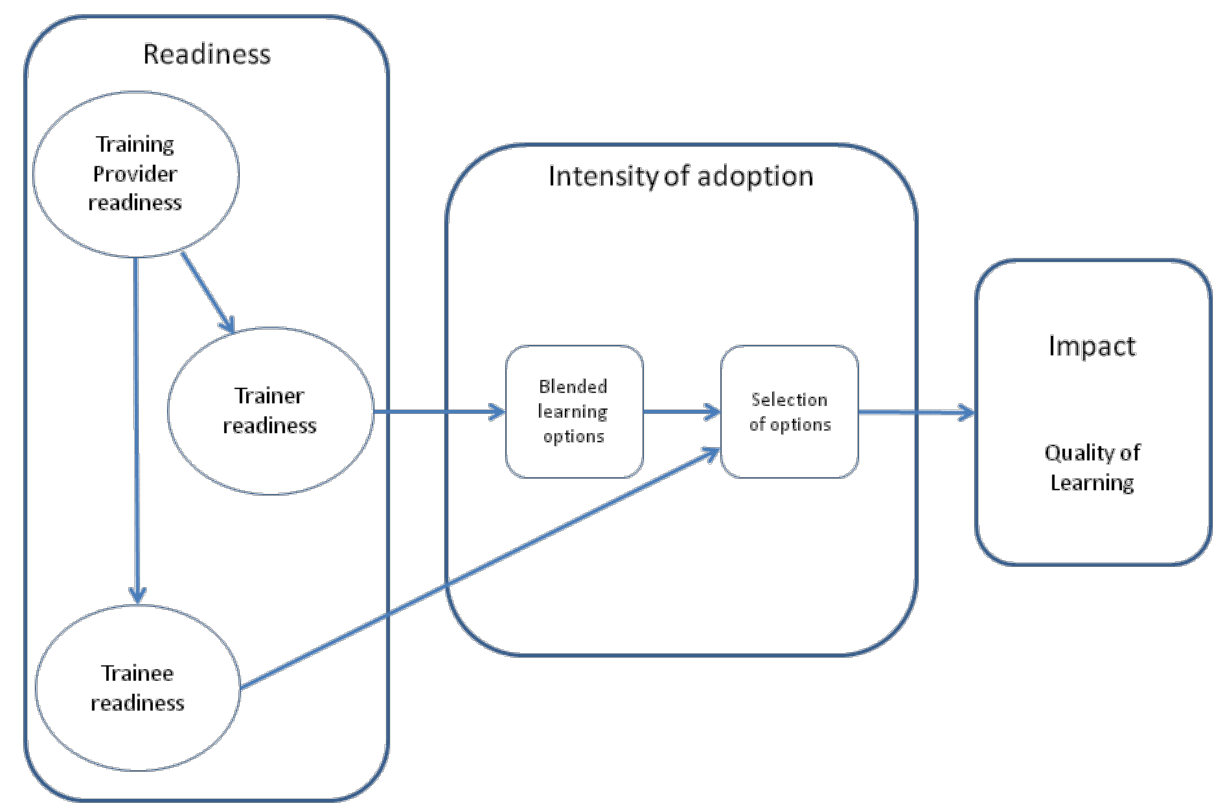

Figure 1: Blended Learning Assessment (BLA) Framework: tailored for Tradespeople (amended from Wong, et al. 2014)

The Wong et al. (2014) framework was initially developed for use by higher education institutions and was meant to provide an overview of the blended learning experience with regards to readiness, intensity of adoption and impact. In Figure 1, the terms 'training provider', 'trainer' and 'trainee' have replaced the higher education terms 'higher education institution', 'staff' and 'student' to reflect the emphasis on industry training in this article as opposed to higher education course delivery.

The BLA framework discusses three aspects that should be considered when delivering a blended learning program: Readiness - of the training provider, trainers and trainees to adopt the blended learning program; Intensity of adoption - the suite of blended learning options implemented and the selection of those options by students; and, Impact - assessing the quality and extent of learning achieved.

The BLA framework has obvious overlap with Fayolle and Gailly's (2008) Teaching Model Framework where the learner readiness relates to 'for whom?' in the teaching framework, 
selection of blended learning options relates to the 'what?' and 'how?' aspects of the teaching framework and impact relates to the 'for which results?' aspect of the teaching framework.

The following sections discuss each aspect of the BLA framework.

\subsubsection{Readiness}

Readiness is a term that has been employed to determine how 'ready' a business is to adopt ICT. Parker (2000) described eReadiness as how prepared a business is to operate in an eBusiness marketplace. Similarly, Machado (2007) developed a framework for assessing eReadiness in higher education institutions. Machado's framework differentiates between the roles of administrators, instructors and students. This view of readiness was adopted by Wong et al. (2014) in their BLA framework. For them, readiness incorporates factors such as the availability of infrastructure and skilled workers, finance to introduce blended learning initiatives, the willingness to use ICT within the organisation and the attitudes of senior management. From an organisational viewpoint (training provider readiness) it is important that the ICT infrastructure used to support blended learning is in place (Elliot and Clayton, 2007). The institution needs to achieve 'buy in' from staff (who will be trainers) and provide suitable training for designers and users of blended learning where they are lacking in relevant skills (Valentine, 2011).

From the viewpoint of the trades entrepreneur, readiness refers to: their level of time commitment, basic technical proficiency, confidence and interest in the blended learning approach. Additionally, participants must have access to the technology being used in the training program and adequate support in how to use it (Valentine, 2011).

\subsubsection{Intensity of adoption}

For Wong et al. (2014), intensity of adoption relates to the selections made by instructors when deciding what features to incorporate into their blended learning package and the subsequent choices made by learners as to which of these features to use.

\section{Blended learning options}

Wong et al. (2014) suggest that different approaches to delivery could be assembled as part of an overall blended learning package. These different approaches could be classified according to the level of ICT support that they rely upon, using a continuum of blended learning that the authors extended from the work of Jones, et al. (2009). The stages identified in the continuum range from Face-to-face (no ICT support) through to E-intensive (complete online delivery). In between lies a mix of face-to-face and online delivery, such as that which occurred in the course that is the focus of this article.

Approaches to teaching can also vary from an instructional to a more learner-centred approach. A learner-centred teaching approach requires learners to be more involved in determining their own learning experience and sometimes even negotiating how this might occur. Such experiences can occur if learning activities are structured to pose questions or problems, and then students search for solutions themselves and assess the relevance of any information they have found in their own context (Emes \& Cleveland-Innes, 2003). This fits well with a blended learning environment where the participants select which program delivery features to use.

With a traditional (instructional) approach, the teacher acts as 'expert', sourcing or developing and delivering resources and making judgements regarding content and assessment. Löbler (2006) refers to this as the 'transmission' approach. The role of the teacher is that of a transmitter 
of content and the role of the learner is that of a passive consumer. The predetermined curriculum forms the basis of transferring knowledge to the learner. Interaction occurs between instructor and learners. Typical activities include listening (to instructors), reading (assigned materials) and memorizing.

When discussing the notion of education in the context of entrepreneurship, Fayolle and Gailly (2008) distinguished between teaching (such as imparting a knowledge or skill; instructing; conditioning an action) and educating (for instance, developing capacity; stimulating mental growth and so forth). The authors suggest that, since entrepreneurship refers to individual initiative, creativity and even innovation, the notion of educating seems more appropriate to entrepreneurs than teaching. This implies that entrepreneurs would be well-suited to a learner-centred approach.

\section{Selection of options}

The selection of options by trainees can be affected by the approach to delivery. With a learnercentred approach, students are likely to have more freedom to select blended learning options that suit their own situation and search for their own solutions to problems raised within the course (Emes \& Cleveland-Innes, 2003). An instructional approach is more likely to prescribe the use of blended learning options (Löbler, 2006).

Learner-centred approaches do not necessarily preclude the use of instructional approaches, but learners can choose from a set of learning elements that allow them to consider the instruction in their own context and transform the instruction into learning (De GeorgeWalker \& Keeffe, 2010). Typical activities in this approach involve experiential, 'open-ended' learning activities, where "neither students nor the instructor has prior knowledge of all of the results" (Emes \& Cleveland-Innes, 2003, p.60). For entrepreneurs, this can create an environment that supports "autonomy, self-reliance, independent thinking and in general the ability of self-governing" (Löbler, 2006, p.31). Such active learning is highly suited to an environment where the aim is to apply general knowledge gained in a specific context (theory to practice). From an entrepreneurial learning viewpoint, a learning-centred approach provides the type of environment that encourages double loop learning (gradual change in behaviour over time) rather than single loop learning, which relates to how to solve a specific problem or instance (Pittaway and Thorpe, 2012).

\section{Other Intensity of adoption issues}

The other key aspect of blended learning, not emphasised in Wong et al's (2014) BLA framework, is the need for the ICT infrastructure to remain operational throughout the delivery of the program (Elliot and Clayton, 2007). Strategies need to be put in place to support the use of the technology during this time (Valentine, 2011), which would include dealing with situations when all or part of the technology is not operational (either due to technical fault or lack of user skills).

\subsubsection{Impact}

Impact can be assessed in several ways - such as the level of usage of different features, learner satisfaction levels and the effect on overall performance (Wong et al., 2014).

Evaluation is also a key aspect of Fayolle and Gailly's (2008) teaching framework as evaluation criteria are decided at the time of designing the program. The assessment of the impact of blended learning initiatives allows the effect of the separate blended learning options on 
students to be determined. The different options can be assessed with regards to the aims of the program, the content and the approach taken by the deliverers. For instance, Mullin (2013) examines the use of online learning to assist in the delivery of courses of varying lengths to hairdressing apprentices in England. Impact was assessed through questions asked during separate focus groups of trainers and apprentices. It was generally regarded that the program made a positive contribution to learning. It was "fun and motivating" (Mullin, 2013, pp.74-75) and had the potential to speed up course completion.

An assessment of the success of a blended learning approach should include reference to any improvements in accessibility that the learners have to the various aspects of the program due to the nature of its delivery. For instance, one of the advantages that online learning can provide over traditional face-to-face delivery for organisations is increased flexibility in training options due to: flexibility in time (delivery at a time that suits); flexibility of place (selection of design and delivery options); and, flexibility of delivery (to varied numbers of learners concurrently) (Elliott and Clayton, 2007).

This is particularly suited to tradespeople who are often time poor and 'practically minded' learners who prefer variety regarding the methods used to train them. A blended learning approach to trades training may be preferable (Bruce, 2012). Fayolle and Gailly (2008, p.579) refer to the possibilities offered by ICT:

Indeed in entrepreneurship as in almost all disciplines, the growing use of ICT ... tend[s] to develop and offer to a certain extent more autonomous ways of learning, outside of the classroom and far from the more traditional and dependent methods of learning.

\section{Research Methodology}

This project was conducted at Victoria University (an Australian metropolitan university) and was funded by the Telematics Trust with the aim of developing 'Enabled Tradie', a blended learning program to support tradespeople in the adoption of ICT tools appropriate to their businesses.

\subsection{Research questions}

This article adopts Wong et al.'s (2014) Blended Learning Framework as a lens to describe a research project examining a case study involving the use of blended learning to encourage entrepreneurial learning through building ICT capacity. This also provided an opportunity to test the framework for its effectiveness outside of the environment in which it was developed, undergraduate higher education. In doing this, the researchers considered the following research questions (developed around sections of the framework):

- What was the preparedness of the university, instructors and tradespeople for the blended learning program? (Readiness)

- What combination of blended learning options was provided for the tradespeople (Intensity of Adoption)? (Jones et al., 2009)

- How was the quality and extent of learning (Impact) assessed for the program?

- What were the advantages of blended learning delivery for participating tradespeople? (Elliott and Clayton, 2007; Mullin, 2013). 
- Was the blended learning program able to provide suitable skills to tradespeople about basic and context relevant ICT use? (Walker, 2001).

The article concludes by proposing a version of the blended learning framework that is specifically tailored for training entrepreneurs.

\subsection{Study approach}

This study involves an interpretivist case study of six tradespeople who were the owner/managers of their businesses and who were interested in building their ICT awareness. As an interpretivist study, the aim is to develop the blended learning framework for these and similar entrepreneurs. The amended framework could then be tested and validated in later studies. As such, the research design is based on inductive reasoning and the research questions are interpreted in a more flexible manner than would occur in a positivist study (Williamson, 2013) to build theory rather than test it. They not only investigate the blended learning program under review, but they also help to guide the development of the revised blended learning framework for entrepreneurs in trades and similar vocational areas.

Cope and Watts (2000) conducted a case study involving six small business owners when investigating the role of critical incidents in entrepreneurial learning. Their study confirmed the case study as an appropriate methodology to design learning programs, an approach also used by De George-Walker and Keefe (2010) in the design of a learner-centred blended learning program for undergraduate students. A case study allows for a phenomenon to be examined in its real-life context and typically has multiple sources of evidence and data collection techniques, which were evident here. It is also common in a case study approach for the research questions to have an applied orientation aimed at improving practice (Darke and Shanks, 2002). As indicated earlier in the literature review, improved practice is vital for effective entrepreneurial learning. In this instance, the unit of analysis (Yin, 2003) was individual participants and, by implication, the businesses that they operated.

Another key approach used in this study was action research, where the researchers are involved in the topic and are part of the process of bringing about change. This occurs in a setting that is not 'detached' as would occur in more traditional research approaches (Veal, 2005). Action research involves an approach that is critically reflective. When an action occurs, its effect is assessed and modifications to the research approach are made if needed. A cycle of Plan - Action - Results - Reflection - Plan is typical of the action research process (Oosthuizen, 2002). As such, it is often difficult to plan ahead of time how a particular action research cycle will pan out. It is important to define and explain the role of the researcher in action research and, thus, the approaches to the evaluation of the research need to be carefully considered (Oosthuizen, 2002). The specific role of the researchers in this project is described in Section 3.4. Additionally, the Results and Discussion sections outline how the researchers reflected upon (and altered) the modes of delivery and the content of the course as it was being delivered.

\subsection{Participant Selection}

It was hoped to source 10-12 participants in a small number of trades occupations as a purposive sample to run the blended learning program as a trial of a larger roll-out of the program at a later date. General invitations for participation were sent out via a local government mailing list and the Victoria University 'global' mailing list, asking for contacts to potential participants. This resulted in nine responses from tradespeople who were provided 
with further details about the proposed program. Of these, six tradespeople agreed to participate, with the non-participants explaining that the time requirements of the course were too demanding or that the course was too basic for their needs.

The final grouping of tradespeople participating in the program was as follows: a handyman, an electrician (who had to drop out half way through the program due to work pressures); a fitter and turner who had moved into specialist maintenance; two hairdressers and a café proprietor who also provided external catering services (who had heard about the program and asked to participate.).

The participants were all owner/managers. 'Pre-participation' surveys (to be explained further in Section 3.5) suggested that they were keen to develop their businesses into sustainable and competitive small enterprises.

It is reasonable to assume that the fact that the participants were proactive and motivated enough to engage with the program indicated that they were energetic and innovative fundamental entrepreneurial characteristics as described by Gray and Gonsalves (2002). However, the small number of participants means that it would be difficult to state that all small businesses would be suited to this form of study program. However, the study is well suited to identifying the main components of the blended learning framework for entrepreneurs in the trades and similar vocations.

\subsection{Design of the program}

A unique aspect of the program is that student mentors were introduced to support the learning process. The mentoring was provided by employing Victoria University business students (selected, trained and managed by the research team). The aim was that mentors would conduct follow up sessions (face-to-face and via asynchronous technologies) with participants to assist in the initiation and integration of ICT adoption. Mentors are considered to provide the following benefits to the entrepreneur (Perren, 2003):

- $\quad$ one-to-one relationship;

- $\quad$ the mentor is more experienced than the entrepreneur (in the relevant subject matter). In our program, it would be more accurate to say that the student mentors were more knowledgeable than the entrepreneurs in the subject matter.;

- the focus is on growth and development of the individual, and

- $\quad$ a confidential and protected relationship exists between mentor and mentee.

The authors of this article ('the researchers') were involved in the design and delivery of the blended learning program. Two student mentors were employed to liaise with the businesses and assist them to tailor aspects of the course material to their specific businesses (context). Each student was assigned three businesses to mentor. Whilst it was understood that the students were not experienced business practitioners, they were very well-performed in a range of business units and could use technologies likely to be trialled by the businesses. It was expected that they would also benefit from having exposure to different businesses and the ability to add the experience to their curricula vitae. The mentors were themselves mentored by the researchers with regards to how to interact with the businesses and when to offer advice. They were encouraged to seek advice from the researchers throughout the program and to report regularly on their progress (as described later). 
The program ran for 11 weeks in early 2013. Face-to-face sessions were initially held at the Victoria University campus where the researchers were based. Use of technology for program delivery was limited to that available within the university at the time. In the first session, participants were shown how to access the university network and to access the website of the blended learning program, which was set up using the Learning Management System, Blackboard. Figure 2 shows the opening Blackboard screen for the program. The Blackboard interface used by Victoria University could not be described as 'mobile friendly', although it could be access by smartphones and tablets.

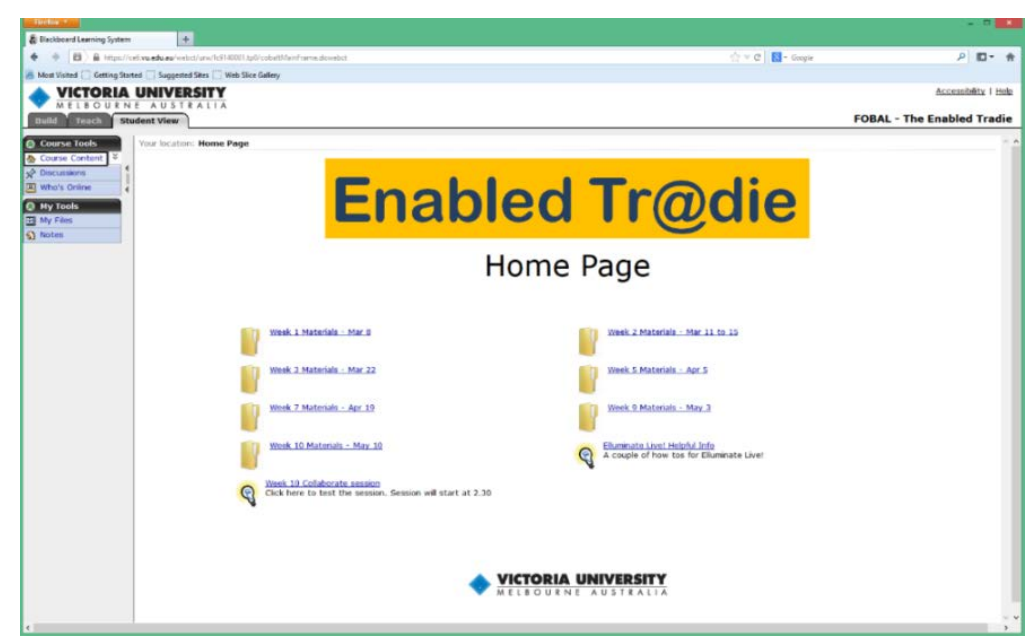

Figure 2: Opening screen of the 'Enabled Tradie' blended learning program Blackboard website.

It was decided that the program should commence with some face-to-face sessions so that the participants could meet with the program instructors and mentors. These were held in professional development rooms of Victoria University. These rooms combine computer projection facilities (via large screen televisions situated around the room) and computers on desktops. They provide a different experience from the traditional lecture room, tutorial room or computer laboratory. Refer to Figure 3 for an image of the professional development room used in the program.

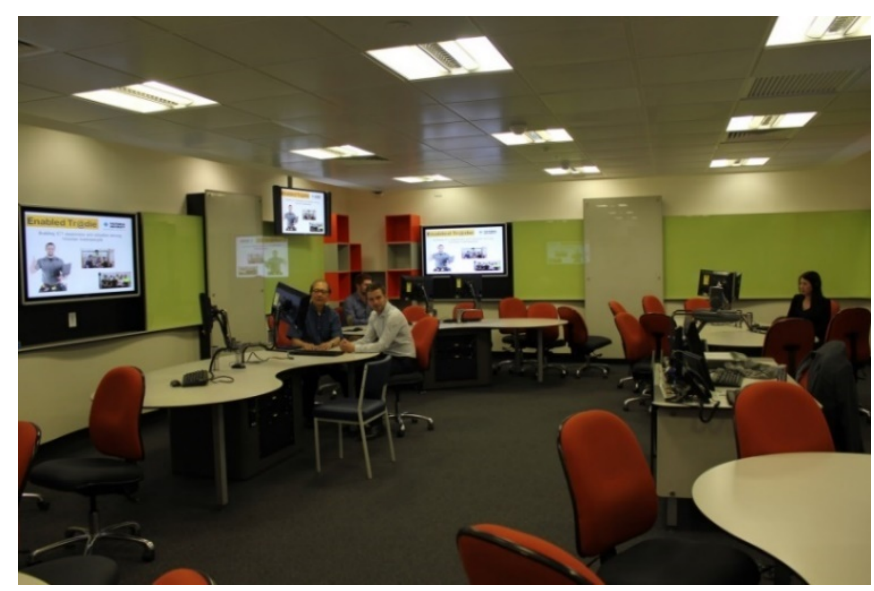

Figure 3: Professional Development room used for face-to-face sessions

Returning to the program design, the aims of the early face-to-face sessions were to provide the opportunity for participants, instructors and mentors to meet each other and to familiarise themselves with the requirements of the program. A final face-to-face session was conducted 
at the end of the program. Afternoon tea was provided in all face-to-face sessions as an 'ice breaker'.

However, the researchers understood the challenges faced by participants regarding attending face-to-face sessions during regular work hours. It was difficult to find a common time where all participants were able to attend the sessions (a challenge noted by Walker, 2001). Not all of the participants were able to attend the two face-to-face sessions at the beginning of the program. In these instances, the mentors provided an overview of the session when they met up with participants during their business visits. After two introductory face-to-face sessions, a series of four online sessions was arranged. Although the sessions required the participants to be available in real time, their travel time was significantly reduced by not having to attend the university campus. These sessions used an online conferencing tool linked to Blackboard Collaborate that allowed a presenter to deliver 'live' audio while Microsoft PowerPoint slides were viewed by participants. Participants were provided with headsets (with microphones) and were assisted with setting these up on their home computers by their mentors. An option was available for the software to be used on tablets, but this was not selected by any of the participants. The online tool allowed them to ask questions via the microphone, comment via a 'chat' facility, participate in voting sessions and indicate certain 'emotions' (through 'like' and 'smiley face' emoticons). The sessions were generally well 'attended' and were recorded for participants to view later on the few occasions that they were not able to participate. Participants who could not participate cited work reasons for their non-participation.

A key aspect of the program was the interface between the researchers (as deliverers of the program), the mentors and the participants. Vital to this was the relationship between the mentors and their associated businesses. These relationships were key to the ability of participants to be able to take the generic concepts presented in the face-to-face and online sessions and apply them to their specific businesses. The interaction between the mentors and their businesses was strong throughout the program.

Other blended learning activities were introduced as support activities for the program. Online support materials were provided to allow participants the opportunity to access further resources about specific topics that were covered in the sessions, or find out further information about topics of interest. These resources were used sparingly by some participants and more enthusiastically by others. Online tests were provided as revision for the face-to-face and online sessions. These were not used to any great extent and were thus discontinued during the program. Regular practical exercises were provided to encourage participants to work by themselves or with their mentors to determine how generic concepts could be applied to their businesses. These exercises were embraced by the participants.

\subsection{Data collection and analysis}

Data collection for the research occurred in several ways alongside (and after) the delivery of the blended learning program, as follows:

- $\quad$ Participants were requested to complete surveys in the first week of the program ('preparticipation' survey) and the last week of the program ('post-participation' survey). There was also a follow-up interview conducted by one of the authors with each participant some 12 months after the completion of the course. The surveys contained mostly open-ended questions. The initial survey helped to formulate the content of the 
course, whilst the other survey and final interview were used to ascertain the views of participants regarding the success of the course.

- Student mentors were asked to provide regular reports (three each throughout the program) that outlined how participants were progressing, the challenges that the participants faced and the aspects of the course that the mentors thought had worked well. The mentors were also asked to complete a self-assessment at the end of the program to indicate the depth of their own self-development.

- Throughout the course, participants were asked to complete exercises related to the program, either independently or in conjunction with their mentors. The outputs of these exercises were not assessed, but they were discussed, and they provided some insights that were used in the development of the program and reporting of results in this article.

- Additionally, the reflections of the authors (as program deliverers) were used in the presentation of results in this article.

All of the above (except for the author reflections) were either already in MS Word format, were transcribed into MS Word files or were documents that were scanned. These were all entered in the qualitative software analysis program NVivo. MS Word documents and scanned files were imported as 'sources' into folders under the names of the participants and student mentors. Separate nodes relating to the research questions were set up (as 'themes') and the results were analysed according to these themes.

\section{Results}

This section addresses the research questions from the perspective of the blended learning program under review. The research questions relate to the Wong et al. (2014) BLA framework and provide a lens via which the results can be presented. The following description of the BLA program is based upon the main stages of the BLA framework. Section 4.1 presents an updated version of the BLA framework, proposed for entrepreneurs in trades and similar vocational areas.

\subsection{Readiness}

The first research question was what was the preparedness of the university, instructors and tradespeople for the blended learning program? University readiness was discussed in Section 3.4. The level of readiness of participants was partly known ahead of program delivery as it was requested that participants at least had access to a smart phone or a suitable device to access the Internet. Thus, the researchers anticipated that any problems would relate more to usage aspects of the digital divide rather than problems relating to access to ICT.

It was apparent at that early stage that the participants were, as anticipated, in a good position with regards to possessing ICT devices to access the course materials. Four of the six participants indicated little or no use of ICT in the workplace, but there was recognition by all participants that ICT could potentially improve their work practices. The areas that they regarded themselves as most competent in were the use of email and web browsers, as well as taking digital pictures via their smartphones.

The readiness of staff (the researchers) was already known and meant that access to the facilities required for delivering the program was in place and the skills were available to 
facilitate this. However, the researchers were not experienced in the use of this technology for external course delivery to this cohort and thus the delivery of the program provided some challenges for them that were not anticipated (such as expectations regarding how long it took for tradespeople to master the use of the remote technology). Table 1 summarises the readiness assessment.

\begin{tabular}{|l|c|}
\hline $\begin{array}{l}\text { BLA } \\
\text { Framework } \\
\text { Stage }\end{array}$ & \multicolumn{1}{c|}{ Blended Learning Approach } \\
\hline Readiness & $\bullet \begin{array}{l}\text { ICT available and already used by researchers - but they lacked } \\
\text { experience in the use of the technology externally. } \\
\text { Participant readiness assessed via 'pre-participation' survey - they } \\
\text { were well placed to access program material remotely }\end{array}$ \\
\hline
\end{tabular}

Table 1: Blended Learning Program readiness (based on Wong et al. 2014 BLA framework)

\subsection{Intensity of Adoption}

This section examines the question: what combination of blended learning options was provided for the tradespeople? Table 2 shows the variety of options made available, classified according to Wong et al.'s (2014) intensity of adoption framework stage.

\begin{tabular}{|l|l|c|c|c|c|c|c|}
\hline \multicolumn{1}{|c|}{ BLA Framework Stage } & \multicolumn{6}{|c|}{ Blended Learning Approach } \\
\hline & $\begin{array}{l}\text { Blended } \\
\text { learning } \\
\text { options }\end{array}$ & $\begin{array}{c}\text { Face-to- } \\
\text { face } \\
\text { sessions }\end{array}$ & $\begin{array}{c}\text { Mentor } \\
\text { visits }\end{array}$ & $\begin{array}{c}\text { Online } \\
\text { support } \\
\text { materials }\end{array}$ & $\begin{array}{c}\text { Online } \\
\text { tests }\end{array}$ & $\begin{array}{c}\text { Online } \\
\text { sessions }\end{array}$ & $\begin{array}{c}\text { Practical } \\
\text { Exercises }\end{array}$ \\
\cline { 2 - 8 } & $\begin{array}{l}\text { Blended } \\
\text { learning } \\
\text { continuum }\end{array}$ & $\begin{array}{c}\text { Basic ICT } \\
\text { use }\end{array}$ & $\begin{array}{c}\text { Face-to- } \\
\text { face }\end{array}$ & $\begin{array}{c}\text { E- } \\
\text { enhanced }\end{array}$ & $\begin{array}{c}\text { E- } \\
\text { focussed }\end{array}$ & $\begin{array}{c}\text { E- } \\
\text { focussed }\end{array}$ & Varied \\
\cline { 2 - 8 } $\begin{array}{l}\text { Of } \\
\text { Adoption }\end{array}$ & $\begin{array}{l}\text { Perceived } \\
\text { importance } \\
\text { of selection } \\
\text { of options } \\
\text { by } \\
\text { participants }\end{array}$ & $\begin{array}{c}\text { Recomm- } \\
\text { ended }\end{array}$ & Vital & $\begin{array}{c}\text { Recomm- } \\
\text { ended }\end{array}$ & Optional & Vital & Vital \\
\cline { 2 - 9 } \\
$\begin{array}{l}\text { Adoption } \\
\text { by } \\
\text { participants }\end{array}$ & Strong & Strong & Good & Weak & Strong & Strong \\
\hline
\end{tabular}

Table 2: Representation of the Intensity of Adoption of the Blended Learning Program for tradespeople (based on Wong et al. 2014 BLA framework)

In relation to the ideal balance of instructional versus learning-centred delivery, consideration was first given to Walker's (2001) suggestion that the provision of basic technical skills early on in such a program can facilitate later ICT use that is more contextual (applied specifically to the needs of the businesses). As discussed, generic material was covered in face-to-face and online sessions, and this was contextualised for each business via the mentor visits. The researchers made the decision to deliver basic ICT skills at the start of the program and then move to more specific business-related ICT topics later in the program (as per Walker, 2001). This 
combination of basic-to-complex and generic-to-context-specific delivery of ICT concepts is shown in Table 3. Although the overall purpose of the program was to educate rather than teach (Fayolle and Gailly, 2008), it was necessary to set the foundations for this early in the program by using an instructional approach.

\begin{tabular}{|l|c|c|}
\hline Time in program & $\begin{array}{c}\text { Face-to-face or online } \\
\text { session } \\
\text { (Instructional approach) }\end{array}$ & $\begin{array}{c}\text { Mentor visit and practical } \\
\text { exercises } \\
\text { (Learning-centred approach) }\end{array}$ \\
\hline Early sessions & $\begin{array}{c}\text { Generic (basic) } \\
\text { ICT concepts }\end{array}$ & $\begin{array}{c}\text { Context-specific (basic) } \\
\text { ICT concepts }\end{array}$ \\
\hline Later sessions & $\begin{array}{c}\text { Generic (advanced) } \\
\text { ICT concepts }\end{array}$ & Context-specific (advanced) \\
ICT concepts
\end{tabular}

Table 3: Delivery of ICT concepts throughout the blended learning program

The learner-centred approach allowed the tradespeople to select what combination of online support materials, tests and exercises that they wished to complete for their own learning experience, as well as the extent to which they interacted with their student mentor. This also addressed Perren's (2003, p.517) concern regarding entrepreneurs requiring "flexible, learnercentred" approaches.

As an example of how participants applied generic ICT concepts that they were introduced to in the instructional sessions in their own context, one of the exercises in an online class assisted the participants to identify and evaluate 'apps' for use in their businesses. Participants were first introduced to the notion of an innovation or idea having specific characteristics that might influence its adoption (Rogers, 2003). They were then asked to carry out an exercise for their business to identify and evaluate apps that might be useful for them (refer Figure 4). This provided quite different results for the participants. The handyman tested and evaluated an app for forecasting the weather as much of his work was conducted outside. The hairdresser examined apps relating to accounts and record keeping for hairdressers and another app that suggested different hair styles for clients. 


\section{EnabledTr@die}

\section{Assessing ICT investments}

\section{Week 5 Exercise}

Work on this exercise with your mentor. Examine some software and apps that might be suitable for your business. Assess them according to the criteria below.

\begin{tabular}{|c|c|c|}
\hline Factor & Definition & Typical issues \\
\hline Relative Advantage & $\begin{array}{l}\text { Improvement over previous } \\
\text { operations (eg cheaper?, faster?; } \\
\text { more information?) } \\
\text { Remember to take the cost (SSS } \\
\text { and your time) into account - } \\
\text { and that most ICT has a setup } \\
\text { and ongoing maintenance cost }\end{array}$ & $\begin{array}{l}\text { A smartphone with a camera might } \\
\text { allow you to provide a more detailed } \\
\text { quote; or remove doubt about the } \\
\text { specifics of a task to be carried out }\end{array}$ \\
\hline Compatibility & $\begin{array}{c}\text { How easily it fits with what you } \\
\text { are already doing }\end{array}$ & $\begin{array}{l}\text { An Android app will not work with an } \\
\text { iPhone or and iPad; } \\
\text { Can you print to your existing printer } \\
\text { with your tablet? }\end{array}$ \\
\hline Complexity & $\begin{array}{l}\text { How difficult you think it will be } \\
\text { to use? }\end{array}$ & $\begin{array}{l}\text { A spreadsheet might be handy for the } \\
\text { business, but are you able to set one } \\
\text { up? Do you need to pay someone else } \\
\text { to do that for you? }\end{array}$ \\
\hline Trialability & Do you get the chance to try it? & $\begin{array}{l}\mathrm{PC} / \mathrm{Mac} \text { software often comes with } \\
\text { trial versions that operate for a short } \\
\text { time or with limited functionality; } \\
\text { Apps often come with 'free" versions } \\
\text { that can be upgraded to paid versions }\end{array}$ \\
\hline Observability & $\begin{array}{l}\text { Have you seen it in operation? } \\
\text { Have others reviewed it? }\end{array}$ & $\begin{array}{l}\text { Do you have friends or colleagues that } \\
\text { use it? Have you read reviews of the } \\
\text { innovation by other people in your } \\
\text { industry or by unbiased computer } \\
\text { magazines? Can you view videos that } \\
\text { demonstrate of how software or apps } \\
\text { work? }\end{array}$ \\
\hline
\end{tabular}

Figure 4: Sample participant exercise 


\begin{tabular}{|c|c|c|c|}
\hline Week & Interaction & Initial Program & Amended Program \\
\hline 1 & $\begin{array}{l}\text { Face-to-face } \\
\text { session }\end{array}$ & Welcome; Introduction & Welcome; Introduction \\
\hline 2 & \multicolumn{2}{|c|}{ Mentor business visit; online revision } & \\
\hline 3 & $\begin{array}{l}\text { Face-to-face } \\
\text { session }\end{array}$ & $\begin{array}{l}\text { Tablets \& smartphones; } \\
\text { Customer interaction }\end{array}$ & $\begin{array}{l}\text { Tablets \& smartphones; Security, } \\
\text { privacy and storage (moved forward) }\end{array}$ \\
\hline 4 & \multicolumn{2}{|c|}{ Mentor business visit; online revision } & \\
\hline 5 & Online session & $\begin{array}{l}\text { Security, privacy and } \\
\text { storage; Peripherals }\end{array}$ & $\begin{array}{l}\text { Customer interaction (moved back) } \\
\text { Assessing ICT investments (ADDED) }\end{array}$ \\
\hline 6 & \multicolumn{2}{|c|}{ Mentor business visit; online revision } & \\
\hline 7 & Online session & $\begin{array}{l}\text { Quotations; scheduling } \\
\text { jobs; Office software }\end{array}$ & $\begin{array}{l}\text { Quotations; job scheduling; Office } \\
\text { software }\end{array}$ \\
\hline 8 & \multicolumn{2}{|l|}{ Online revision } & \\
\hline 9 & $\begin{array}{l}\text { Mentor business } \\
\text { visit; Online } \\
\text { session }\end{array}$ & Invoice and payment & $\begin{array}{l}\text { Invoice and payment } \\
\text { Internet basics (ADDED) }\end{array}$ \\
\hline 10 & Online session & $\begin{array}{l}\text { Software as a service; } \\
\text { Setting up a website }\end{array}$ & $\begin{array}{l}\text { Setting up a website } \\
\text { Portals and Directories (ADDED) }\end{array}$ \\
\hline 11 & $\begin{array}{l}\text { Face-to-face } \\
\text { workshop }\end{array}$ & Review & $\begin{array}{l}\text { Software as a service (moved back); } \\
\text { ICT and work-life balance (ADDED); } \\
\text { Future ICT trends (ADDED) }\end{array}$ \\
\hline
\end{tabular}

Table 4: Blended Learning Program: Initial and Amended Program

Table 4 shows the topics of the blended learning program from the initial program (as originally conceived) to the amended program (delivered). Alterations were made after the initial face-to-face session in Week 1 (when ICT expertise of participants was assessed). This is an example of how the program fitted the action research approach, as well as demonstrating the learner-centred approach that was undertaken. The amended program shows topics that were moved from later in the program to earlier ('moved forward'), topics delayed ('moved back') and new topics added to the program ('added').

The content of the course was initially determined by the instructors, based upon many years' experience in delivering basic ICT concepts to business undergraduate students and research into the use of ICT by small businesses. Several changes in course content were initially made on the basis of the responses to the 'pre-participation' survey in Week 1 of the course. For instance, after the initial week the researchers realised that participants lacked an understanding of basic ICT concepts and thus would benefit from knowing about the basics of security, privacy and data storage of information on ICT systems earlier, so this topic was moved forward from Week 5 to Week 3. Subsequently, as deficiencies in ICT knowledge were identified by instructors throughout the course, other changes were made. For example, a new topic, assessing ICT investments, was added to Week 5. 
In other weeks, topics related to basic understanding of the Internet and the use of business directories and portals were also added. These were examples of how the researchers identified during the course that the participants required more background about ICT basics. The flexible nature of the program design allowed these topics to be incorporated.

The next section discusses the evaluation of the blended learning program.

\subsection{Impact}

This section addresses the research question: how was the quality and extent of learning (Impact) assessed for the program? It includes reference to the following sub-questions:

- What were the advantages of blended learning delivery for participating tradespeople?

- Was the blended learning program able to provide suitable skills to tradespeople about basic and context relevant ICT use?

Participants were asked to complete a 'post-participation' survey at the end of Week 11 . The survey asked for their overall views of the quality of the program and the different blended learning options that were provided. Regarding those options, participants were asked to rate each option as great (very satisfactory); good (satisfactory); fair (neutral) or not satisfactory and were also requested to provide specific feedback on each approach. According to Lozano, Garcia-Cueto and Muniz (2007) the optimum number of alternatives in rating scales is four to seven. The even number of suggestions were selected to force respondents to lean to a positive or negative response. They were also interviewed one year after the conclusion of the program to ascertain the longer-term effects of the program or the extent of their learning. In addition, the mentors were interviewed after the program to determine their views of the success of the different options. An evaluation of each blended learning option will now be provided, followed by an evaluation of the overall program.

\subsubsection{Face-to-face sessions}

Whilst attendance at the face-to-face sessions was satisfactory (all the participants attended at least one session), there were a few instances when some participants were not able to attend specific sessions. This was always because of their work commitments (as noted by Walker, 2001). One mentor commented that this was a potential limitation of the sessions. All but one of the participants rated these sessions 'good' or 'great'. The café owner rated the sessions as 'fair' and indicated that some aspects were a bit hard to understand as her English was "not great", although this participant also suggested that the "demonstrations (in the sessions) helped with this". The handyman suggested that the classes were good, but "could have had an even greater practical emphasis". Overall, it was considered that the sessions went well, but in future sessions the needs of participants for whom English is not a first language should be considered. The mentors indicated that the sessions were useful, although one mentor suggested that it might have been more useful to have more interactive activities.

\subsubsection{Online sessions}

Figure 5 provides a sample screen of the online sessions as typically viewed by a participant. Again, participation rates were good for these sessions. In the few instances where participants were not available, it was again because of work commitments - although these sessions were easier for participants to participate in due to the reduced travel requirements. 


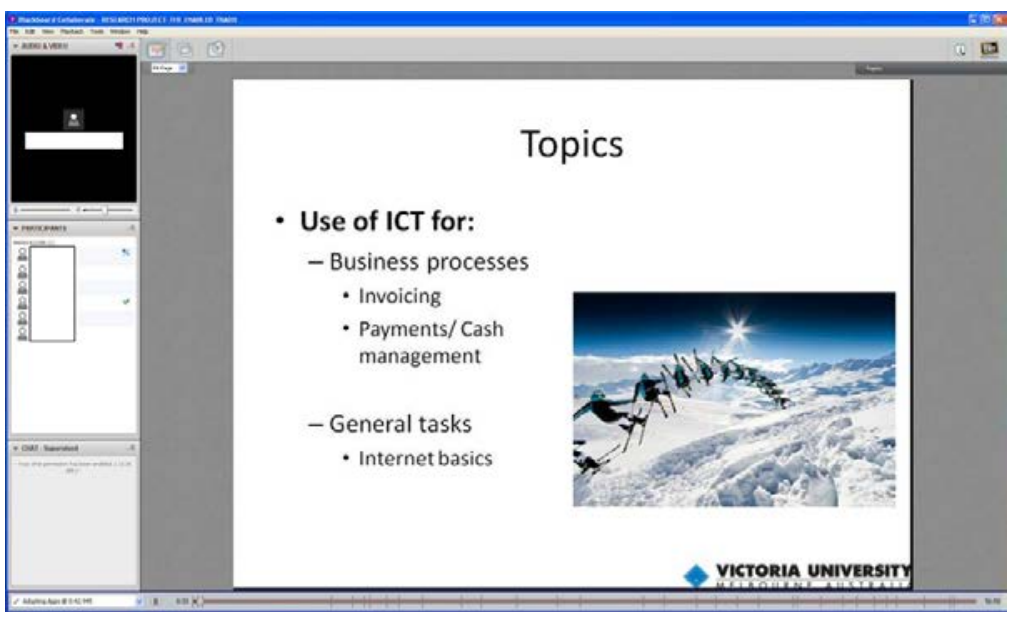

Figure 5: Sample screen from the online sessions (participant details removed)

However, none of the participants rated these sessions as 'great'. There were some technical problems with the sessions, especially early on. All participants were able to view the slides, hear the audio, offer text input via the 'chat' function and use the voting facility. However, some participants had difficulty with setting up audio and were not able to ask questions via their microphones in the early sessions. This is an example of a situation mentioned in the literature review where there could potentially be a problem with ICT infrastructure. There was initially only basic information provided to participants with regards to setting up and participating in the online sessions. The unrealistic expectation was that this would be managed by mentors. One participant suggested that it "would be handy to have rehearsals before the online sessions". Another was not able to comment via microphone until the last online session. Before that he was limited to text comments. He observed that "improved audio is advisable". One mentor commented that "most [of his] participants had communication problems". The café manager noted that it was once again difficult to understand aspects of the sessions when "complicated language was used" and that "this was harder without face-to-face demonstrations".

\subsubsection{Mentor visits}

All participants interacted with their mentors during the allocated periods for mentor visits. This aspect of the blended learning program was rated equal highest by the participants (either 'great' or 'good'). At different times throughout the program, mentors were provided with a 'window' of time to visit their businesses between the face-to-face and online sessions. Each visit was aimed to reinforce the concepts from the previous face-to-face or online session and to provide any other assistance for participants - such as technical assistance (setting up ICT), assisting/ advising on practical exercises (context) and providing clarification on aspects of the sessions that participants were unsure of. The handyman described the mentor visits as a "vital part of connective learning". In support of this, a student mentor commented that the visits were "very necessary. A vital part of the participants' learning. They would not have been able to cross the river without the bridge". The café owner, who had previously commented on the difficulties of understanding aspects of the sessions, added the following feedback:

When I didn't understand the online and face-to-face session because of my English level, the student helped to explain it to me and I understood it better. She showed me how to use the Internet and computer so that I can see for myself and learn. 
The student mentor who had previously mentioned the difficulty for some participants to attend the face-to-face and online sessions observed:

I think these were most useful and accessible given the flexibility of arranging visits. We were able to narrow the information in sessions to their specific industry, making it more relevant and practical. They [the participants] were able to ask questions and learn at their own pace. It was well received, particularly learning how to use the Internet via practical demonstrations.

Overall the participant results indicated that the mentors played a vital role in the conduct of the program.

\subsubsection{Practical Exercises}

As was mentioned earlier, the practical exercises were designed to provide a means by which participants could apply the generic concepts to their businesses. These were rated at the same level as mentor visits by participants ('great' or 'good'). The participant with a maintenance business commented that there should be more practical exercises. The handyman suggested that the exercises allowed concepts to be explored in greater depth. One mentor commented that the exercises were "very important for the participants. This is where they were able to put the pieces to the puzzle together". The café owner indicated that she specifically enjoyed the exercise that allowed her to examine other catering websites for ideas on how to design her own. However, the comments were not all positive. In one exercise, participants were asked to assess the suitability of different software packages for their business. This referred to the specific exercise that was highlighted earlier in the article. A hairdresser commented:

I understand the (softwarelapp) assessment form was to make me think first before I choose to buy, but when the student helped to fill it out for me I didn't really understand the headings. My answers were all the same for every one that I filled out.

The results suggest that the student mentors balanced the need to support the businesses by demonstrating aspects of the course against allowing participants to find things out for themselves quite well. The quoted example might have been one instance where this was not the case. Two other participants indicated that this exercise made them think about evaluating their options in relation to their businesses.

\subsubsection{Online support materials}

All but one participant used the online support materials and rated them between 'fair' and 'great'. Only one participant, however, rated them as 'great'. It appeared that these materials were accessed mainly when participants were searching for more information to help them understand the course content. An example of this was a comment from the café owner: "Most of them [the materials] didn't apply to my catering business but I did find useful the link to terms and guide of what to look for when choosing a computer". The participant who rated the materials as 'great' indicated that they "enabled me to learn more". One participant that rated the materials as 'fair' suggested some difficulties with locating the materials on Blackboard at times. Figure 6 provides an example of how the extra materials were made available to participants. 


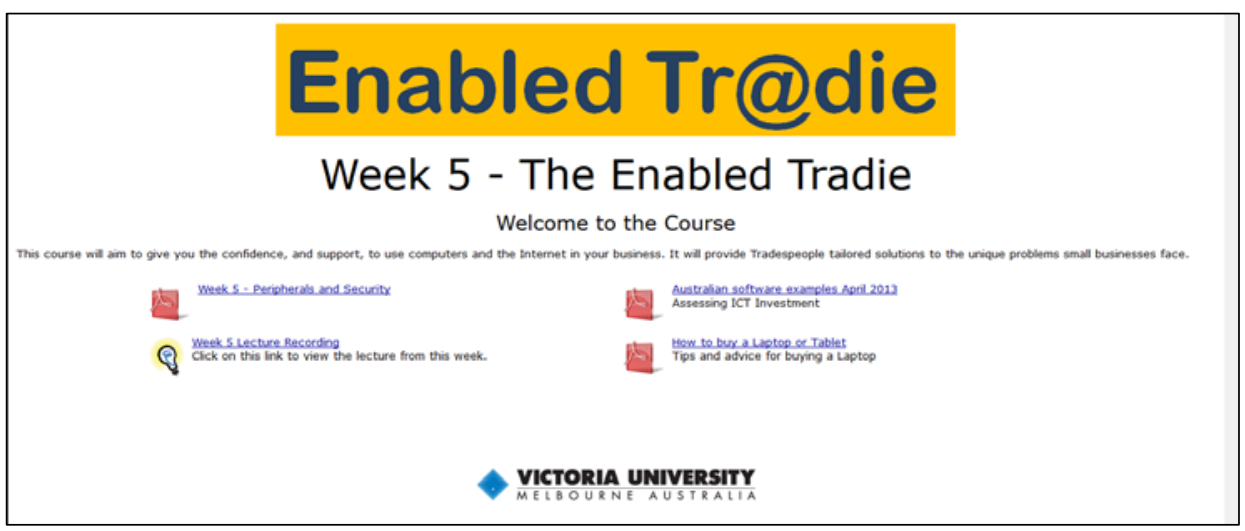

Figure 6: Week 5 of the course content. This shows the support materials for the week-a list of software examples and a guide to buying a laptop or tablet.

The mentors generally supported the views of the participants. One mentor observed that the materials would have been helpful but that there needed to be greater focus placed upon them. The other mentor observed:

The content provided useful information, but in all honesty, I think if we didn't go through them during the mentor visits, I don't think my participants would have explored the links...

To some extent it could be argued that the support materials served their purpose. They were not actually meant to be key components as such - just to provide extra support where needed or selected by participants as part of the learner-centred approach.

\subsubsection{Online tests}

Participants were introduced to the online tests in the first face-to-face session. The tests took the form of a series of multiple choice questions. The tests could be taken at any time by participants and feedback was provided immediately by the system upon completion. The aim of the tests was to reinforce the most basic concepts introduced in the face-to-face and online sessions. However, the online tests were discontinued early in the program due to lack of use by participants. Two comments made by participants were that the tests "were too basic" and "I don't have the time with other tasks I am performing for the class".

\subsubsection{Evaluation of overall program}

In the 'post-participation' survey, participants were asked to rate the extent of their knowledge in relation to the key topic areas covered in the class. All participants indicated an increase in the extent of their knowledge about ICT usage. When asked to elaborate, the following comments were typical:

"Excellent" [handyman]

"I gained further knowledge" [maintenance].

Table 5 summarises the findings of the evaluation of the various components of the blended learning package. Three aspects of the program, face-to-face sessions, mentor visits and supporting practical exercises, were viewed as being vital to the program's success. Perhaps greater emphasis on the practical exercises could be considered in future courses as suggested by some participants. The online sessions were also an important part of the program once the technology problems were overcome. Delivered on a wider scale, the ongoing success of such a program would rely on the technical problems involved in the online sessions being solved. 
The online support materials were not viewed as a vital part of the program but did provide the means for those interested participants to further extend their knowledge if they desired. This enabled them to further tailor the program to their own needs. Although the online tests did not prove to be successful in this program, they should not be ruled out for ongoing programs if some participants require the reinforcement of basic ICT concepts.

An interesting aspect of the evaluation occurred when participants were interviewed one year after the conclusion of the program to ascertain their views of the program and its longer-term effects. All of them indicated that they enjoyed the program and that it had changed their business behaviour in some manner (to varying degrees).

\begin{tabular}{|c|c|c|c|c|c|c|c|}
\hline \multirow{2}{*}{\multicolumn{2}{|c|}{$\begin{array}{l}\text { BLA Framework } \\
\text { Stage }\end{array}$}} & \multicolumn{6}{|c|}{ Blended Learning Approach } \\
\hline & & $\begin{array}{l}\text { Face-to- } \\
\text { face } \\
\text { sessions } \\
\end{array}$ & $\begin{array}{l}\text { Mentor } \\
\text { visits }\end{array}$ & $\begin{array}{c}\text { Online } \\
\text { support } \\
\text { materials }\end{array}$ & $\begin{array}{c}\text { Online } \\
\text { tests }\end{array}$ & $\begin{array}{c}\text { Online } \\
\text { sessions }\end{array}$ & $\begin{array}{l}\text { Practical } \\
\text { Exercises }\end{array}$ \\
\hline \multirow{6}{*}{$\begin{array}{l}\overrightarrow{\tilde{z}} \\
\text { : } \\
\underline{\underline{g}}\end{array}$} & \multirow[t]{2}{*}{ Effectiveness } & \multicolumn{6}{|c|}{$\begin{array}{l}\text { Assessed via: } \\
\text { - } \quad \text { Participant feedback during course } \\
\text { - Intensity of adoption }\end{array}$} \\
\hline & & $\begin{array}{l}\text { 'fair' to } \\
\text { 'great' }\end{array}$ & $\begin{array}{l}\text { 'good' to } \\
\text { 'great' }\end{array}$ & $\begin{array}{l}\text { 'fair' to } \\
\text { 'great' }\end{array}$ & $\begin{array}{c}\text { Not } \\
\text { evaluated }\end{array}$ & $\begin{array}{l}\text { 'fair' to } \\
\text { 'good' }\end{array}$ & $\begin{array}{l}\text { 'good' to } \\
\text { 'great' }\end{array}$ \\
\hline & Observations & $\begin{array}{l}\text { Effective } \\
\text { Could be } \\
\text { difficult to } \\
\text { attend }\end{array}$ & $\begin{array}{l}\text { Resource } \\
\text { intensive } \\
\text { Vital link }\end{array}$ & $\begin{array}{l}\text { Not seen as } \\
\text { mainstream } \\
\text { activity }\end{array}$ & $\begin{array}{l}\text { Too basic } \\
\text { Participants } \\
\text { too busy }\end{array}$ & $\begin{array}{l}\text { Technology } \\
\text { challenges } \\
\text { Useful } \\
\text { when } \\
\text { technology } \\
\text { worked }\end{array}$ & $\begin{array}{l}\text { Bridge } \\
\text { between } \\
\text { sessions, } \\
\text { mentors, } \\
\text { business }\end{array}$ \\
\hline & Response & $\begin{array}{l}\text { Vital to } \\
\text { program } \\
\text { Continue }\end{array}$ & $\begin{array}{l}\text { Vital to } \\
\text { program } \\
\text { Continue }\end{array}$ & $\begin{array}{l}\text { Served their } \\
\text { purpose. } \\
\text { Continue }\end{array}$ & $\begin{array}{l}\text { Not useful } \\
\text { in this } \\
\text { context }\end{array}$ & $\begin{array}{l}\text { Continue, } \\
\text { but need to } \\
\text { sort out the } \\
\text { technology } \\
\text { problems }\end{array}$ & $\begin{array}{l}\text { Vital to } \\
\text { program } \\
\text { Continue, } \\
\text { perhaps } \\
\text { with greater } \\
\text { emphasis }\end{array}$ \\
\hline & \multirow{2}{*}{$\begin{array}{l}\text { Overall } \\
\text { impact }\end{array}$} & \multicolumn{6}{|c|}{$\begin{array}{l}\text { Assessed via: } \\
\text { - ' 'post-participation' survey } \\
\text { - Interviews with student mentors }\end{array}$} \\
\hline & & \multicolumn{6}{|c|}{$\begin{array}{l}\text { - Program was beneficial; worthwhile } \\
\text { - Benefits were evolutionary rather than revolutionary }\end{array}$} \\
\hline
\end{tabular}

Table 5: Representation of the Impact of the Blended Learning Program for tradespeople (based on Wong et al. 2014, BLA framework)

Further, it could be argued that any alterations in behaviour were evolutionary rather than revolutionary, with increased use of the Internet to search for information and mobile devices being the main outcomes. Two of the businesses (handyman and café) had introduced websites due to participation in the program. Other 'new' uses of ICT revolved around use of the Internet for transactions with online purchases being reported by one participant and online banking by another. All participants expressed that the program was worth the effort of participation. 
Overall, the mentors and the participants suggested that the program was a success. This was determined on the basis that all participants indicated that there was an increase in their practical knowledge in the last week of the course (via their 'post-participation' survey) and in the interviews 12 months down the track where they indicated that there had been a change in their business activities due to their participation in the course.

Obviously, there are some issues to be considered before the program could be delivered on a wider scale, but the combination of general sessions, mentor visits and practical exercises provided a useful way to firstly deliver general ICT knowledge and then to cascade this to individual businesses to apply in their own contexts. The success of the program also supported the combination of the instructional approach (for delivery of basic concepts) and the learner-centred approach (for context-specific applications) in the program.

\section{Discussion}

In this section the results presented in Section 4 are compared back to the literature review. When considering the readiness of tradespeople for the blended learning programs, they were well placed to access the course due to their prior use of smart mobile devices, although their usage was basic (email and surfing the web). With regards to the digital divide, participants had physical access to suitable technology but were limited regarding their use of ICT (Srinuan $\&$ Bohlin, 2011). The fact that these businesses agreed to participate in the program indicated that they had an entrepreneurial attitude that lead to them wanting to improve themselves and/or their businesses (Gray \& Gonsalves, 2002). Regarding program delivery, whilst the instructors were experienced in the use of the technology, they had not delivered such programs to groups that were external to the university before. This resulted in some difficulties (such as some of the technical problems that were encountered) that could potentially have been anticipated earlier.

The delivery of the program included activities that ranged between face-to-face and e-focussed on Jones et al.'s (2009) continuum of blended learning. With regards to an appropriate combination of blended learning options for tradespeople (Jones et al., 2009), the participants struggled at times to attend both the face-to-face and online sessions, although not having to travel made it easier for them to access the online sessions. This time restriction faced by tradespeople was also noted by Walker (2001). Even the student mentors had to reschedule their visits on a few occasions as participants' work took first priority. This was the challenge of dealing with entrepreneurs who were self-reliant and did not necessarily work regular hours.

The appropriate balance of instructional versus learning-centred approaches for the tradespeople was achieved. The course was delivered by initially covering the necessary generic ICT skills before moving onto the instructional ICT skills that allowed learning-centred learning to occur, as recommended by Walker (2001). The way participants could work by themselves to apply the concepts delivered in the general sessions to their own unique situations (with the assistance of student mentors where required) allowed this type of learning to occur.

The effectiveness the program was assessed via a number of means. There were certainly indications that the blended learning program allowed for all of the advantages of blended learning as identified by Elliot and Clayton (2007) (flexibility in time; flexibility of place and flexibility of delivery) to occur. However, as indicated earlier, even with the flexible 
approaches, some of the participants struggled to participate at times due to work commitments.

As suggested by Fayolle and Gailly (2008), a range of evaluations (designed around the program) were used to assess the success of the program. All of the participants indicated satisfaction with the program, although their progress could be described as evolutionary rather than revolutionary, with changes to business activities being an important outcome of the program. However, from an entrepreneurial learning viewpoint, they all indicated that they had developed new knowledge that assisted in them in the operation of their businesses. The results of the evaluation suggested that the key aspects of the program were the face-toface sessions, the involvement of the student mentors to visit and work with the businesses and assist them to apply the generic concepts to their business and the practical exercises that assisted them to do this.

\subsection{Limitations and implications}

The program was obviously limited in size due to the small number of participants. A similar program would need to be delivered with a larger group before the researchers could be confident that the program outcomes achieved in this instance could be translated to provide benefits to tradespeople or those in similar vocational areas.

From an entrepreneurial learning viewpoint, the program targeted planned, personal (rather than collective) learning and, as such, conclusions are limited to that sphere. As such, the generalisability of the study is limited.

However, the benefits of the program are promising and the researchers feel that some of the lessons learned during the delivery of this blended learning program reflect the issues that were identified in the literature and could potentially be applied to the delivery of ICT concepts to entrepreneurs in the trades and similar vocations:

- The notion of starting with general ICT concepts and then branching out to more context-specific ICT topics was effective (Walker, 2001).

- When selected carefully, student mentors can provide a vital and cost-effective means of converting generic ICT concepts into business-specific applications (context).

- A well-planned group of practical exercises to support these activities are vital.

- $\quad$ Entrepreneurs are often limited regarding the time they can devote to these types of courses (Walker, 2001). The provision of different blended learning options can help to overcome these problems by offering flexibility of time, place and delivery (Elliott and Clayton, 2007).

- $\quad$ Any use of ICT for blended learning should be accompanied by a level of technical support that provides effective access and use of that technology - otherwise participants may find themselves victims of a form of digital divide (Srinuan and Bohlin, 2011) regarding the technology being used to deliver the program.

\subsection{Amended version of framework for entrepreneurs in the trades and similar vocations}

Whilst the Wong et al. (2014) BLA framework had been developed through the delivery of blended learning to undergraduate higher education students, it had not been applied outside of this environment. Refer to Figure 7 for a proposed update to the framework, specifically 
tailored for entrepreneurs working in the trades or in similar vocational areas. This has been developed in an inductive manner based on results presented in Section 4 . When revisiting the framework, a few immediate issues can be considered. The overall ICT infrastructure will typically be put in place by the training provider, but entrepreneurs will need to have access to ICT devices (such as PCs, tablets and/or smartphones) to use the system. Trainers will need to have the skills to develop learning materials for the blended learning package and a positive attitude towards doing so (as per Wong et al. 2014). One of the obvious findings of the study was the enthusiasm (positive attitude) that participants had towards the program (as discussed in the Methodology section). The skills to use the technology are also important for entrepreneurs. The need to consider training provider infrastructure; entrepreneurs' access to ICT devices, skill level and enthusiasm; and the skills and attitudes of trainers have been added to the Readiness section of the BLA framework.

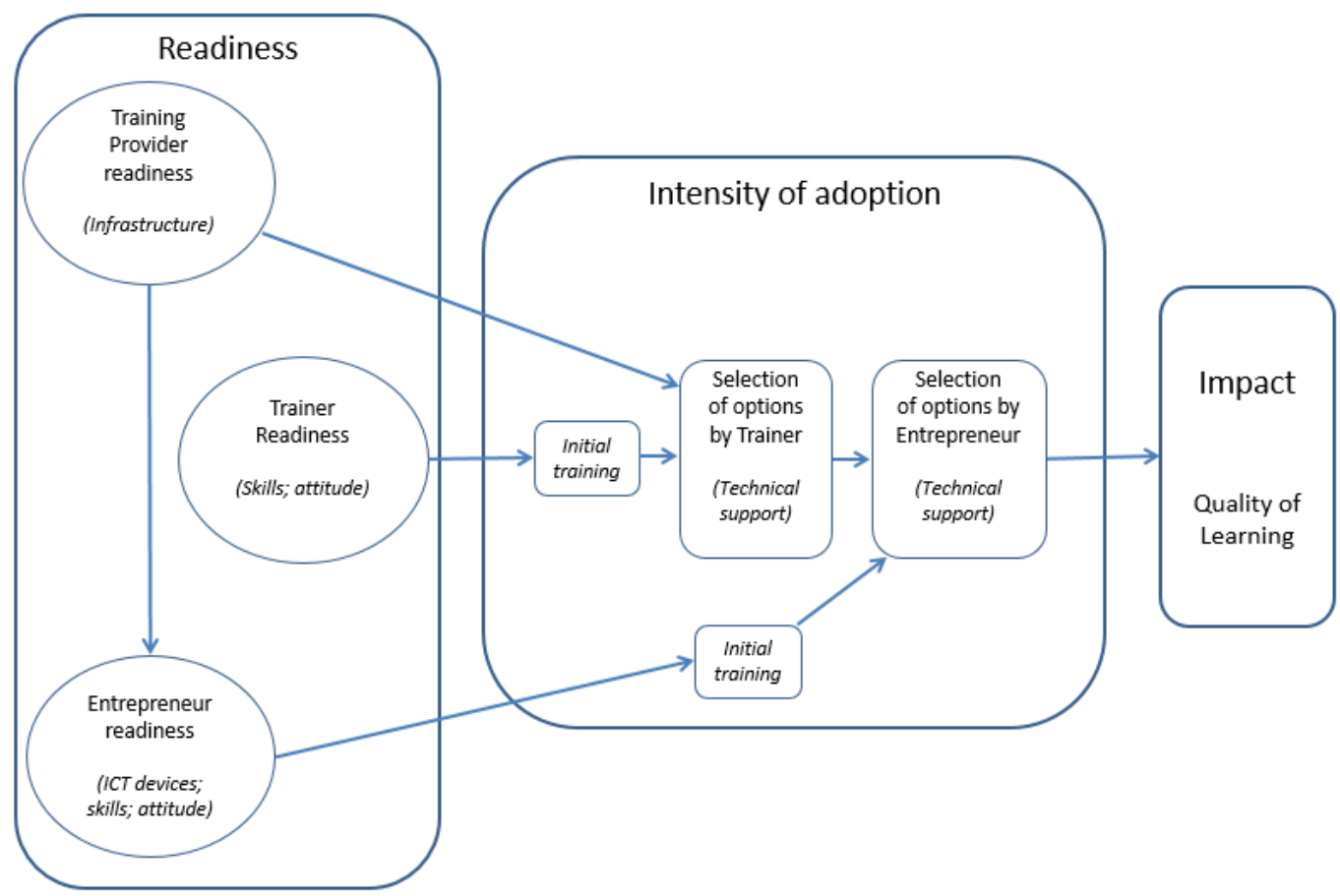

Figure 7: Revised Blended Learning Assessment framework for entrepreneurs in the trades and similar vocational areas (amended from Wong et al., 2014).

Note also there is now a direct link from training provider readiness to the selection of blended learning options by the trainer, as the ICT infrastructure will influence the availability of options for trainers to select from. The Intensity of adoption section has two important additions that have been added because of the study. The first relates to the provision of adequate training for trainers (to develop blended options and associated curricula) and entrepreneurs (to effectively access and use the system). There is also a recognition that technical support will likely need to be provided to both trainers and entrepreneurs throughout the conduct of the program. Note that the framework does not stipulate the types of training and support provided for the system, just that it should be evident. The Impact section of the framework remains unchanged, with the quality of learning remaining the key objective to be measured. It could potentially be argued that improvements to the small business could also be added here and might be considered in future implementations of the framework. Academics assessing blended learning programs for similar groups should find the amended framework 
useful as it maintains the Readiness, Intensity of adoption and Impact aspects of the Wong et al. (2014) framework, but introduces other key considerations as key aspects of such a blended learning program.

\section{Conclusion}

This article examined the development and delivery of a pilot blended learning program designed to assist a group of tradespeople to build their ICT capacity as part of a proactive entrepreneurial learning exercise for planned, personal learning rather than collective learning. In doing this, Wong et al.'s (2014) Blended Learning Assessment framework was used to identify the processes that are key to the successful implementation of such programs: determining the readiness of instructors to deliver and enterprising business operators to take part in the program; considering the blended learning options available and how they are adopted by participants (intensity of adoption) and determining the program's impact through an evaluation of the different blended learning options delivered and the program overall. Consideration of all of these factors ensured a comprehensive evaluation of the program. Whilst the combination of face-to-face and online sessions were effective for delivering basic ICT concepts to motivated participants, some participants faced pressures regarding freeing up the time from their employment to participate. The combination of student mentor visits and practical exercises provided an effective way for business operators to apply the basic ICT concepts into context specific applications for their businesses. The project also demonstrated how a combination of instructional approaches (for the delivery of basic ICT concepts) and learning-centred approaches (for context-specific applications) facilitated the eventual successful outcomes of the program - highlighting the importance of educating rather than teaching entrepreneurs (Fayolle and Gailly, 2008) to achieve effective entrepreneurial learning. The experience of delivering the program informed the development of a revised blended learning framework for entrepreneurs working in the trades or in similar vocational areas (a theoretical contribution of this article), as well as the provision of potential lessons for the delivery of ICT concepts to these entrepreneurs.

\section{Acknowledgement}

The authors acknowledge the important assistance of the Telematics Trust in providing the funds for the conduct of the program reported in this article.

\section{References}

Australian Bureau of Statistics (2012). Australian Small Business: Key Statistics and Analysis December 2012, Canberra, Australia: Commonwealth of Australia.

Biggs, J., \& Tang, C. (2011). Teaching for quality learning at university (4th ed.). Berkshire, England: McGraw-Hill International.

Bliuc, A., Goodyear, P., \& Ellis, R. A. (2007). Research focus and methodological choices in studies into students' experiences of blended learning in higher education. The Internet and Higher Education, 10(4): 231-244.

Bound, H. (2011). Vocational education and training teacher professional development: Tensions and context. Studies in Continuing Education, 33(2): 107-119.

Bruce, J. (2012). Discipline specific e-training for trades tutors. Waikato, New Zealand: Ako Aotearoa. 
Burgess, S., Sellitto, C., \& Karanasios, S. (2009). Effective web presence solutions for small businesses: Strategies for successful implementation. Hershey, PA: Information Science Reference.

Cambridge University Press. (2013a). English definition of ICT. Cambridge Dictionary. Retrieved from http://dictionary.cambridge.org/dictionary/business-english/ict, [Accessed 3 December 2013].

Cambridge University Press. (2013b). English definition of tradesperson. Cambridge Dictionary. Retrieved from http://dictionary.cambridge.org/dictionary/businessenglish/tradesperson?q=tradesperson; [Accessed 3 December 2013].

Cope, J., \& Watts, G. (2000). Learning by doing-an exploration of experience, critical incidents and reflection in entrepreneurial learning. International Journal of Entrepreneurial Behaviour \& Research, 6(3): 104-124.

Darke, P., \& Shanks, G. (2002). Case study research. In K. Williamson (Ed.), Research methods for students, academics and professionals: Information management and systems (2nd ed). (pp.111-124). NSW, Australia: Centre for Information Studies, Charles Sturt University.

De George-Walker, L., \& Keeffe, M. (2010). Self-determined blended learning: A case study of blended learning design. Higher Education Research \& Development, 29(1), 1-13.

Deloitte. (2012) Digital disruption - Short fuse, big bang?, building the lucky country: Business imperatives for a prosperous. Stories from the digital frontline. Australia. Retrieved from http://www.deloitte.com/au/digitaldisruption, [Accessed 4 April 2014].

Elliott, R., \& Clayton, J. (2007). E-learning for New Zealand industry training organisations: Analysis of benefits and barriers. ICT: Providing Choices for Learners and Learning. ASCILITE Proceedings, Singapore: ASCILITE.

Emes, C., \& Cleveland-Innes, M. (2003). A journey toward learner-centred curriculum. The Canadian Journal of Higher Education, 33(3), 47-70.

Erdélyi, P. (2010). The matter of entrepreneurial learning: A literature review. International Conference on Organizational Learning, Knowledge and Capabilities 2010, Boston, US: OLKC.

Fayolle, A., \& Gailly, B. (2008). From craft to science: Teaching models and learning processes in entrepreneurship education. Journal of European Industrial Training, 32(7): 569-593.

Fernandes, P. (2016). Entrepreneurship defined: What it means to be an entrepreneur. Business News Daily. March 2, Retrieved from https://www.businessnewsdaily.com/7275entrepreneurship-defined.html [Accessed 8 January 2018].

Gasson, S, \& Waters, J. (2013). Using a grounded theory approach to study online collaboration behaviors. European Journal of Information Systems, 22(1): 95-118.

Gray, C., \& Gonsalves, E. (2002). “Organizational learning and entrepreneurial strategy". The International Journal of Entrepreneurship and Innovation, 3(1): 27-33.

Harrison, R. T., \& Leitch, C. M. (2005). Entrepreneurial learning: Researching the interface between learning and the entrepreneurial context. Entrepreneurship Theory and Practice, 29(4): 351-371.

Jones, P., Simmons, G., Packham, G., Beynon-Davies, P., \& Pickernell, D. (2014). An exploration of the attitudes and strategic responses of sole-proprietor micro-enterprises 
in adopting information and communication technology. International Small Business Journal, 32(3): 285-306.

Jones, N., Chew, E., Jones, C., \& Lau, A. (2009). Over the worst or at the eye of the storm? Education Training, 51(1): 6-22.

Kirkup, G. (2010). Vocational education and training (VET) for ICT employment: Preparing women for work. In Women and ICTs through the Lifecycle, Barcelona, Spain: UOC.

Löbler, H. (2006). Learning entrepreneurship from a constructivist perspective. Technology Analysis \& Strategic Management, 18(1): 19-38.

Lozano, L., Garcia-Cueto, E. \& Muniz, J. (2007). Effect of the Number of Response Categories on the Reliability and Validity of Rating Scales, Methodology, 4(2): 73-79.

Machado, C. (2007). Developing an e-readiness model for higher education institutions: Results of a focus group study. British Journal of Educational Technology, 38(1): 72-82.

Martin, L. M., \& Wright, L. T. (2005). No gender in cyberspace?: Empowering entrepreneurship and innovation in female-run ICT small firms. International Journal of Entrepreneurial Behaviour \& Research, 11(2): 162-178.

Mullin, T. (2013). Cutting edge or cut loose? an exploration of apprentices' experiences of workplace e-learning. Journal of Vocational Education \& Training, 65(1): 66-86.

Niblock, S. (2013). Media professionalism and training (Key Concerns in Media Studies Series ed.). UK: Palgrave Macmillan.

Oosthuizen, M. J. H. (2002). Action research. In K. Williamson (Ed.), Research methods for students, academics and professionals: Information management and systems (2nd ed.). (pp. 159-176). Wagga Wagga, NSW, Australia: Centre for Information Studies, Charles Sturt University.

Overby,E., Slaughter, S., \& Konsynski, B (2010). The Design, Use and Consequences of Virtual Processes, Information Systems Research, 21(4): 700-710.

Parker, S. (2000). A survey of small business in Colorado. Colarado, USA: Colorado Community College and Occupational Education System.

Perren, L. (2003). The role of e-mentoring in entrepreneurial education and support: A metareview of academic literature. Education + Training, 45(8/9): 517-525.

Pittaway, L., \& Thorpe, R. (2012). A framework for entrepreneurial learning: A tribute to Jason Cope. Entrepreneurship \& Regional Development, 24(9-10): 837-859.

Rogers, E. M. (2003). Diffusion of innovations (5th ed.). New York: The Free Press.

Srinuan, C., \& Bohlin, E. (2011). Understanding the digital divide: A literature survey and ways forward. 22nd European Regional Conference of the International Telecommunications Society, Budapest, Hungary: International Telecommunications Society.

Telstra Corporation. (2013). Sensis E:Business report: The online experience of small and medium enterprises. Australia: Sensis.

Valentine, E. (2011). ICT in vocational education and training: A view of information and communication technology in vocational education in New Zealand. Wellington, New Zealand: Tertiary Education Commission and Service Industry Training Alliance. 
van Praag, C.M. \& Versloot, P.H. (2007). What is the value of entrepreneurship? A review of recent research. Small Business Economics. 29(4): 351-382.

Veal, A. J. (2005). Business research methods: A managerial approach (2nd ed.), Australia: Pearson Education Australia/Addison Wesley.

Walker, S. (2001). ICTs and innovation in trade unions: Internet training in European trade union confederations and worker education organizations. Human Resources Global Management Conference, Barcelona, Spain: Cranet and Esade.

Willliamson, K. (2013). Research Concepts, in Williamson, K. \& Johanson, G. (eds). Research Methods: Information, Systems and Concepts. Prahran, Australia: Tilde University Press.

Wong, L., Tatnall, A., \& Burgess, S. (2014). A framework for investigating blended learning effectiveness. Education + Training, 56(2/3): 233-251.

Yin, R. K. (2003) Case study research: Design and methods (3rd ed.). London, UK: Sage.

Copyright: (C) 2018 Burgess, Bingley, Paguio \& Woodley. This is an open-access article distributed under the terms of the Creative Commons Attribution-NonCommercial 3.0 Australia License, which permits non-commercial use, distribution, and reproduction in any medium, provided the original author and AJIS are credited.

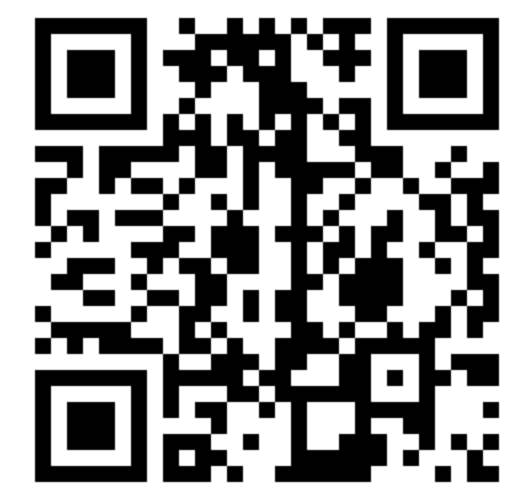

